Int. J. Plant Sci. 180(3):232-239. 2019. (C) 2019 by The University of Chicago. All rights reserved. This work is licensed under a Creative Commons Attribution-NonCommercial 4.0 International License (CC BY-NC 4.0), which permits non-commercial reuse of the work with attribution. For commercial use, contact journalpermissions@press.uchicago.edu.

1058-5893/2019/18003-0006\$15.00 DOI: 10.1086/701819

\title{
HEDYOSMUM-LIKE FOSSILS IN THE EARLY CRETACEOUS DIVERSIFICATION OF ANGIOSPERMS
}

\author{
Else Marie Friis, ${ }^{1, *}$ Peter R. Crane, $\mathbf{t}^{\prime} \neq$ and Kaj Raunsgaard Pedersen§ \\ *Department of Palaeobiology, Swedish Museum of Natural History, Stockholm, Sweden; +Oak Spring Garden Foundation, 1776 Loughborough \\ Lane, Upperville, Virginia 20184, USA; ¥Yale School of Forestry and Environmental Studies, New Haven, Connecticut 06511, USA; \\ and §Department of Geoscience, University of Aarhus, Aarhus, Denmark
}

Editor: Maria von Balthazar

\begin{abstract}
Premise of research. Early Cretaceous Hedyosmum-like fossils are important because they provide information on the pistillate flowers and fruits of plants that produced Asteropollis pollen, which is common and widely distributed very early in the history of angiosperms. Hedyosmum (Chloranthaceae) is also the only extant genus for which there is a plausible fossil presence at such an early stage of angiosperm evolution.
\end{abstract}

Methodology. The fossils were sieved out of unconsolidated sediments and cleaned with HF, HCl, and water. External morphology and internal anatomy were studied using scanning electron microscopy and synchrotron radiation X-ray tomographic microscopy.

Pivotal results. New information on Hedyosmum-like fossils is provided based on pistillate flowers and fruits with adhering Asteropollis pollen from the Early Cretaceous of Portugal. The fossils are assigned to a new Early Cretaceous taxon, Hedyflora crystallifera, which in external morphology is closely similar to extant Hedyosmum. However, the fossils differ from the extant genus in having a crystalliferous endotesta with cells that have endoreticulate infillings, a feature characteristic of all extant Chloranthaceae except Hedyosmum. Extant Hedyosmum has a thin, unspecialized seed coat. This new discovery confirms earlier predictions that an endotestal seed coat is ancestral for Chloranthaceae as a whole but has been lost in the lineage leading to extant Hedyosmum.

Conclusions. Hedyflora confirms the divergence of the Hedyosmum lineage from other Chloranthaceae very early in the angiosperm radiation but refutes these early fossils as evidence of extant Hedyosmum in the Early Cretaceous.

Keywords: Asteropollis, Chloranthaceae, early angiosperms, fossil flowers, fossil fruits, fossil seeds, SRXTM, synchrotron X-ray microtomography.

\section{Introduction}

Phylogenetic analyses based on molecular sequence data resolve extant Chloranthaceae, with just four living genera (Ascarina J.R.Forst. \& G.Forst., Chloranthus Sw., Hedyosmum Sw., Sarcandra Gardner), as among the earliest diverging lineages of extant angiosperms (Angiosperm Phylogeny Group IV 2016). All four genera are relatively species poor and of restricted geographic occurrence today (Todzia 1993). The differentiation of the Chloranthaceae very early in angiosperm evolution is also consistent with paleobotanical data that identify the family as one of the oldest extant angiosperm clades that can be recognized in the fossil record, with a geological history based on dispersed pollen extending back to the mid Early Cretaceous, about 130 Myr ago (Couper 1958, 1960; Walker and Walker 1984; Friis et al. 2011).

Flowers of extant Chloranthaceae are extremely simple, but they are nevertheless surprisingly disparate and exhibit unusual

1 Author for correspondence; email: else.marie.friis@nrm.se.

Manuscript received October 2018; revised manuscript received November 2018; electronically published February 7, 2019. features that have been difficult to explain based on analyses of extant taxa alone (e.g., Swamy 1953; Endress 1987; Eklund et al. 2004). Early Cretaceous fossils possessing transitional combinations of features, however, provide important keys to unraveling evolutionary patterns in the family. Two fossil structures, Canrightia E.M.Friis \& K.R.Pedersen (2011) and Canrightiopsis E.M.Friis, G.W.Grimm, M.M.Mendes \& K.R.Pedersen (2015), have been especially crucial for understanding the unique and long-debated nature of the unusual androecium in extant Chloranthus and Sarcandra. Canrightia and Canrightiopsis reduce the morphological gap between the flowers of Hedyosmum with well-developed tepals and the naked flowers of Chloranthus and Sarcandra. They imply an evolutionary sequence from the radially symmetrical flowers of Canrightia to extant Chloranthus and Sarcandra, as well as fossil Canrightiopsis and Chloranthistemon P.R.Crane, E.M.Friis \& K.R.Pedersen, by retention of the hypanthium, loss of the perianth, reduction in number of ovules and stamens, and displacement of the stamens to the dorsal side of the ovary on top of the hypanthium (Friis et al.2015). Here we describe Hedyosmum-like pistillate floral structures from the Early Cretaceous of Portugal. Previously these fossils have been interpreted as indicating a possible Early Cretaceous age for 
crown group Hedyosmum (Friis et al. 2005), but synchrotron Xray microtomography now reveals critical features that distinguish these fossils from extant Hedyosmum. The new information is important for understanding the evolutionary history of the Chloranthaceae and for reconciling the structure of Hedyosmum flowers with those of other extant Chloranthaceae.

\section{Material and Methods}

The fossil flowers and fruits were extracted from Early Cretaceous sediment samples collected from the Arazede, Buarcos, Catefica, and Vale de Água localities in western Portugal. In these areas, the Cretaceous sequence is typically thick and may include several stratigraphic ages (e.g., late Aptian to early Campanian in the Figueira da Foz-Buarcos area; Dinis et al. 2008; Friis et al. 2011). The plant-bearing sediments studied here from Arazede, Buarcos, and Vale de Água are assigned to the basal part of the Figueira da Foz Formation, which is indicated to be of late Aptian-early Albian age based on stratigraphic correlations (Dinis et al.2008). The sediments from Catefica are from the lower part of the Almargem Formation of probable Aptian age (Dinis et al. 2010). For additional information on the geology and age of the localities, see also Friis et al. (2011). The fossils were retrieved from the sediments by sieving in water. Adhering mineral matrix was removed by $\mathrm{HF}$ and $\mathrm{HCl}$, followed by rinsing in water (e.g., Friis et al. 2009, 2018a). Extant flowers and fruits of Hedyosmum from herbarium specimens were examined without further treatment.

Specimens for SEM were mounted on aluminum stubs with nail polish, coated with gold, and studied with a Hitachi S-4300 field-emission or Phillips 515 scanning electron microscope. Specimens for attenuation-based synchrotron radiation X-ray tomographic microscopy (SRXTM) were mounted on brass stubs using nail polish and examined at the TOMCAT beamline of the Swiss Light Source at the Paul Scherrer Institute, Villigen, Switzerland (Stampanoni et al. 2006). SRXTM analyses were carried out at $10 \mathrm{keV}$ using an $\times 10$ objective (isotopic pixel size, $0.65 \mu \mathrm{m}$ ) or $\times 20$ objective (isotopic pixel size, $0.325 \mu \mathrm{m}$ ) combined with a scientific complementary metal-oxide-semiconductor detector and a 20- $\mu \mathrm{m}$ thick LAG:Ce scintillator screen. Vertical stacking was applied for several specimens, and twofold lateral extension (Friis et al. 2014) was applied for the analysis of extant Hedyosmum orientale Merr \& Chun.

All S-numbered specimens and raw data from the SRXTM study are stored at the Swedish Museum of Natural History in Stockholm, Sweden (S). New names of fossil plants are registered in the Plant Fossil Record Registry, which is hosted and operated by the National Museum Prague for the International Organisation of Palaeobotany (IOP), each with a unique plant fossil name number.

\section{Results}

Descriptions of the Fossils and Taxonomic Treatment

Angiospermae

Family-Chloranthaceae

Hedyflora E.M.Friis, P.R.Crane \& K.R.Pedersen gen. nov.
Derivation of generic name. From the name part Hedy in Hedyosmum and flos (Latin for flower) to indicate the close similarity to the extant genus.

Generic diagnosis. Flowers, unisexual, apedicellate, epigynous, with one whorl of three free tepals at the top of a triangular ovary. Hypanthium with lateral depressions (windows). Ovary unilocular with a single pendant, orthotropous, and bitegmic ovule. Stigma one. Fruit a nut. Seed endotestal; endotesta of a single layer of endoreticulate and crystalliferous cells; exotegmen of a single layer of sclerenchyma cells.

Comments on the genus. Flowers and fruits of Hedyflora are closely similar to those of extant Hedyosmum. Both have epigynous flowers with three tepals at top of the hypanthium and unusual depressions (windows) in the hypanthium (e.g., Endress 1971) that have not been described for other angiosperms. The seeds of Hedyflora differ, however, in having a single layer of endoreticulate crystal cells and a sclerenchymatic exotegmen, which contrasts with the undifferentiated testa and tegmen of extant Hedyosmum. In seed organization and features of the seed coat, Hedyflora is closely similar to extant Ascarina, Chloranthus, and Sarcandra as well as extinct Canrightia, Canrightiopsis, Kvacekispermum E.M.Friis, P.R.Crane \& K.R.Pedersen (2018b), Rightcania E.M.Friis, P.R.Crane \& K.R.Pedersen (2018b), and pistillate structures associated with Chloranthistemon (Crane et al. 1989), but none of these taxa have the epigynous organization and three tepals at the top of the hypanthium as seen in $\mathrm{He}$ dyflora and Hedyosmum.

Type species designated here. Hedyflora crystallifera E.M.Friis, P.R.Crane \& K.R.Pedersen gen. et sp. nov.

Plant Fossil Names Registry number. PFN000136 (for new genus).

Hedyflora crystallifera E.M.Friis, P.R.Crane \& K.R.Pedersen gen. et sp. nov. (Figs. 1A-1I, 2A-2C)

Derivation of specific epithet. From the crystalliferous endotesta.

Specific diagnosis. As for the genus.

Holotype designated here. S101738 (Buarcos sample 157; illustrated here in fig. $1 A-1 C)$.

Paratypes designated here. S101600-S101604, S101724S101737, S101743-S101746, S175200 (Buarcos sample 157), S175201-S175204 (Buarcos sample 209), S101532, S101740S101742, S175205 (Buarcos sample 210), S175206, S175207 (Buarcos sample 211), S175208, S175209 (Buarcos sample 244), S172328 (Buarcos sample 371).

Plant Fossil Names Registry number. PFN000137 (for new species).

Description and remarks on the species. Hedyflora crystallifera is described based on about 260 pistillate flowers and fruits with adhering pollen grains from the type locality at Buarcos. The pistillate structures are always isolated with no indication of a pedicel and without remains of subtending bracts. They are obovate to angular-obovate in longitudinal section, triangular in transverse section with sharp edges, and about $0.8-1.3 \mathrm{~mm}$ long and $0.5-0.9 \mathrm{~mm}$ wide. Most specimens are abraded and strongly compressed and were probably preserved in the anthetic stage. However, the same fossil assemblage from Buarcos also includes three-dimensionally preserved flowers and fruits that show the tepals as well as internal details (fig. $1 A-1 D$ ). The flowers are 

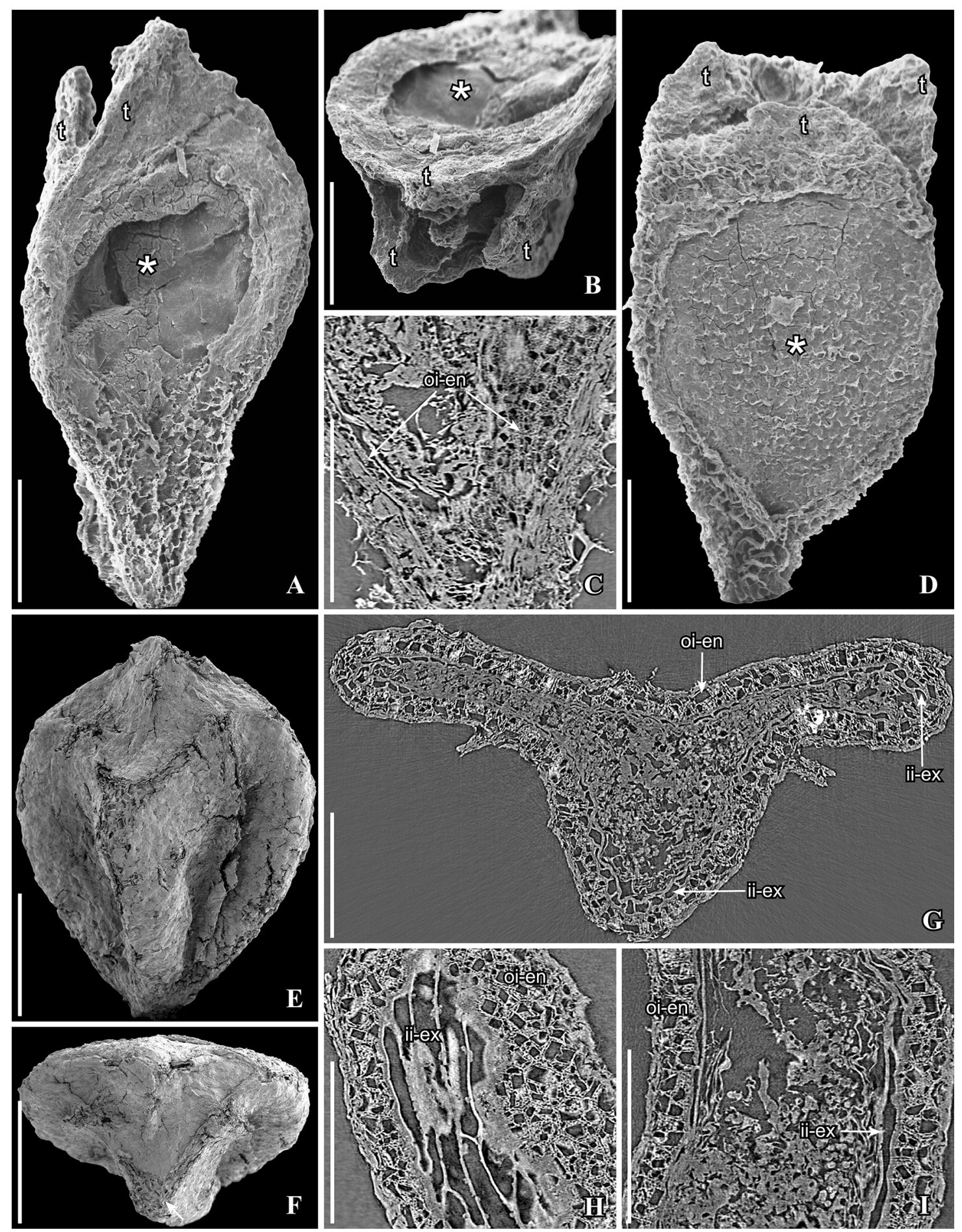

Fig. 1 SEM images $(A, B, D-F)$ and synchrotron radiation X-ray tomographic microscopy reconstructions (orthoslices, $C, G-I)$ of pistillate flowers and fruits of Hedyflora crystallifera gen. et sp. nov. from the Early Cretaceous (late Aptian-early Albian) of Portugal. A, B, Holotype; lateral $(A)$ and apical $(B)$ views of pistillate flower showing small, triangular tepals $(\mathrm{t})$ at the top of hypanthium with papillate depression (asterisk) in the hypanthium surface (S101738; Buarcos sample 157). C, Longitudinal orthoslice (orthoslice yz0907) of holotype (same as $A, B$ ) through basal part of fruit and seed, showing the crystalliferous endotesta with endoreticulate infillings (oi-en). $D$, Lateral view of flower showing three tepals $(\mathrm{t})$ at the top of hypanthium with papillate depression (asterisk) in the hypanthium surface (S101600; Buarcos sample 157). E, F, Lateral $(E)$ and apical $(F)$ view of a fruit showing the triangular shape of gynoecium, abraded perianth, and base of style (S174186; Vale de Àgua sample 329). G-I, Transverse $(G$, orthoslice xy1200) and longitudinal ( $H$, orthoslice yz0864; $I$, orthoslice xz1049) orthoslices through the same fruit as in $E$ and $F$, showing the crystalliferous endotesta with endoreticulate infillings (oi-en) and exotestal fibers (ii-ex). Scale bars $=250 \mu \mathrm{m}(A, B, D-F), 125 \mu \mathrm{m}(C, G-I)$. 
unisexual and epigynous with three free, broadly triangular tepals at the top of the hypanthium (fig. $1 A, 1 B, 1 D$ ). The hypanthium wall forms three raised ridges along the three corners and three distinct windows (depressions) over the lateral faces. These depressed areas (windows) are wide (fig. $1 A, 1 B, 1 D$ ) and characterized by small papillae on the outer epidermis (fig. $1 D$ ), but often the epidermis is strongly compressed or abraded (fig. $1 \mathrm{~A}$, $1 B)$. The cells below the epidermis have slightly undulate anticlinal walls.

The gynoecium is monocarpellate with a pointed base and apex. The stigma is extended but is typically abraded or abscised. The ovary is uniovulate with a single orthotropous and pendant ovule. Seed coat structure has been observed in specimens from several localities: three from Buarcos (type locality, S101600, S101738, S172328), one from Vale de Água (S174186), one from Arazede (S174481), and one from Catefica (S172325). Internal structure is particularly well preserved in the Vale de Água specimen (fig. 1E-1I). The tepals and hypanthium are abraded in this specimen, which is probably preserved at fruiting stage because there is a fully developed seed containing remains of endosperm and embryo. The seed is bitegmic and endotestal. The endotesta is about $25 \mu \mathrm{m}$ thick and composed of a single layer of crystal cells (fig. 1C, 1G-1I). The crystals themselves are missing, leaving angular spaces. These spaces are surrounded by fibers that fill the remaining cell lumen and form a fine internal reticulate mesh (fig. $1 H, 1 I$ ). The exotegmen consists of one layer of sclerenchymatic, longitudinally arranged fibers (fig. $1 G-1 I$ ).

Pollen grains of the fossil genus Asteropollis Hedlund \& Norris are commonly found adhering to the surface of the flowers and fruits. These grains are particularly abundant on compressed, lignitized specimens from the type locality at Buarcos. An SEM survey of 24 specimens from Buarcos showed Asteropollis grains adhering to 13 specimens, often with numerous grains on each specimen (fig. 2A). Only a single pollen grain that cannot be assigned to Asteropollis was encountered on the 24 specimens.

The pollen grains are typically compressed with a circular outline (fig. 2B). They are about $22 \mu \mathrm{m}$ in diameter, heteropolar and monoaperturate, usually with a tetrachotomocolpate, or rarely trichotomocolpate, aperture. The aperture margins are irregular, not sharply delimited. The aperture membrane is covered by irregular verrucate elements (fig. $2 B$ ). The grains are semitectate-reticulate. The muri are rounded, about $0.4 \mu \mathrm{m}$ wide, with a beaded ornamentation of minute spines in two rows along the edge of the muri (fig. 2C). Columellae supporting the muri are tall and scattered (fig. 2C).

\section{Associated Staminate Structures (Figs. 2D, 2E, 3A-3C)}

Staminate structures with Asteropollis pollen in situ are associated with Hedyflora pistillate structures at several localities. From Buarcos (the type locality for Hedyflora), only isolated compressed stamens have been found. Pollen grains in these isolated stamens are trichotomocolpate and tetrachotomocolpate (fig. $2 D, 2 E$ ) and are very similar in size and tectum configuration to the grains observed on the surface of Hedyflora crystallifera flowers and fruits. It is very likely that these isolated stamens are staminate flowers of the H. crystallifera plant.

Staminate structures with Asteropollis-type pollen are also associated with typical $H$. crystallifera pistillate structures at the Catefica and Vale de Água localities, but there are several differ- ent kinds and it is difficult to establish which is linked to Hedyflora. At both localities (also at the Torres Vedras locality; E. M. Friis, P. R. Crane, and K. R. Pedersen, unpublished manuscript) there are small, almost spherical inflorescences with stamens in densely spaced whorls. These were probably produced by Hedyosmum-like plants but appear immature, and their pollen is poorly preserved. More informative, and with better-preserved pollen, are isolated stamens or small groups of stamens, both of which suggest that the staminate inflorescences may have fallen apart at, or shortly following, maturity. Based on the in situ pollen grains, there appear to be several different species among these specimens. Some stamens contain pollen with exclusively trichotomocolpate apertures, while others contain pollen that is mostly tetrachotomocolpate. There is also considerable variation in pollen size, details of the reticulum, and the shape and density of columellae. For example, the specimen in figure $3 A$ from Vale de Água consists of compressed stamens containing Asteropollis-type pollen grains that are closely similar to those adhering to the Hedyflora flowers in being tetrachotomocolpate with semitectate tectum, beaded muri, and tall, scattered columellae (fig. 3B, 3C), but these pollen grains are smaller than those associated with $H$. crystallifera from Buarcos. It is unknown whether this is because of differences in preservation or because the staminate and pistillate structures were produced by different species.

\section{Discussion}

\section{Hedyflora and Asteropollis}

We can now associate multiple organs with pollen of Asteropollis. Asteropollis includes a single species, Asteropollis asteroides Hedlund et Norris (1968), established based on dispersed heteropolar pollen from the Early Cretaceous (Albian) of Oklahoma. Asteropollis asteroides typically has a star-shaped pentachotomocolpate aperture, but tetrachotomocolpate and hexachotomocolpate grains are also common (Hedlund and Norris 1968; Eklund et al. 2004). An example of the variability in aperture form is provided by an isolated stamen from the Buarcos locality that contains both trichotomocolpate and tetrachotomocolpate grains. The tectum of $A$. asteroides is semitectate-reticulate, with distinctive beaded ornamentation on the muri (Hedlund and Norris 1968; Walker and Walker 1984).

Asteropollis is restricted to Early Cretaceous sediments but during the mid-late Early Cretaceous attained an almost global distribution from Antarctica in the south (Dettmann and Thomson 1987) to Greenland in the north (Koppelhus and Pedersen 1993) and from North America in the west (Hedlund and Norris 1968; Eklund et al. 2004) to Mongolia, China, and Japan in the east (Song et al. 2004; Nichols et al. 2006; Legrand et al. 2014). As first pointed out by Walker and Walker (1984), among extant angiosperms similar pollen is only known for species of Hedyosmum (fig. 3D, 3E).

Flowers that can be confidently linked to Asteropollis, including the Hedyflora flowers and fruits described here, occur abundantly in the Early Cretaceous mesofossil floras of Portugal and, in addition to the material from the Azarede, Buarcos, Catefica, and Vale de Água considered here, are also known from the Famalicão and Torres Vedras localities (Friis et al. 2011). In 

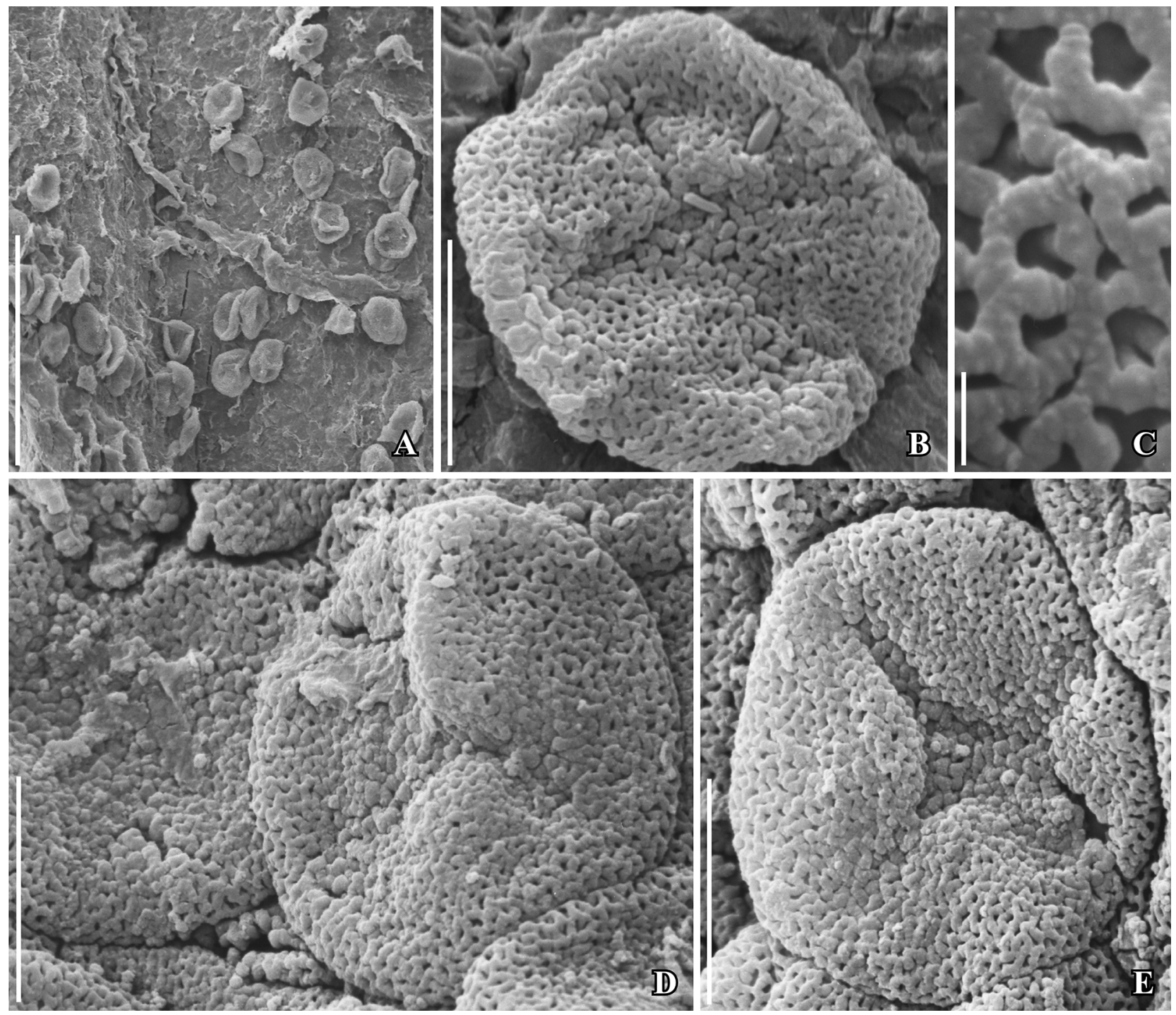

Fig. 2 SEM images of pollen from Hedyflora crystallifera gen. et sp. nov. $(A-C)$ and staminate floral structure $(D, E)$ from the Early Cretaceous (late Aptian-early Albian) Buarcos locality, Portugal. A, Abundant Asteropollis pollen on the surface of a pistillate flower (S101604; Buarcos sample 157). B, Asteropollis pollen from the fruit surface in distal view showing tetrachotomocolpate aperture (S101728; sample Buarcos 157). C, Detail of Asteropollis pollen from the fruit surface showing beaded muri supported by long, scattered columellae; note the ornamentation of two irregular rows of minute spines along the margins of the muri (S101604; Buarcos sample 157). D, E, Asteropollis pollen in situ in an isolated stamen from type locality showing trichotomocolpate $(D)$ and tetrachotomocolpate $(E)$ grains (S101534, Buarcos sample 210). Scale bars $=100 \mu \mathrm{m}(A), 10 \mu \mathrm{m}(B, D$, E), $1 \mu \mathrm{m}(C)$.

several fossil assemblages, staminate structures co-occur with pistillate flowers that often have abundant Asteropollis pollen on the surface (Friis et al. 2011).

Rare Hedyosmum-/Hedyflora-like flowers and fruits have also been discovered in Early Cretaceous Potomac Group sediments from the Puddledock and Kenilworth localities, eastern North America (Friis et al. 1997). However, structural details are not sufficiently well preserved in the North American fossils to confirm that they also had an endotestal seed coat. Also, while dispersed Asteropollis grains are common in Potomac Group sediments (Hedlund and Norris 1968; Doyle and Robbins 1977; Walker and Walker 1984), staminate structures containing these pollen grains have not yet been recovered. Furthermore, intriguing winged and bisexual floral structures related to Hedyosmum/Hedyflora have recently been recovered among the Puddledock mesofossils (E. M. Friis, P. R. Crane, and K. R. Pedersen, unpublished manuscript), indicating that the lineage leading to Hedyosmum was much more diverse in the past and that Asteropollis pollen may ultimately be shown to have been associated with several different kinds of flowers.

\section{Phylogenetic Implications}

All extant Chloranthaceae, as well as all sufficiently wellknown chloranthoid fossils, have orthotropous, pendent, and bitegmic ovules. Except for Hedyosmum, all species have endo- 

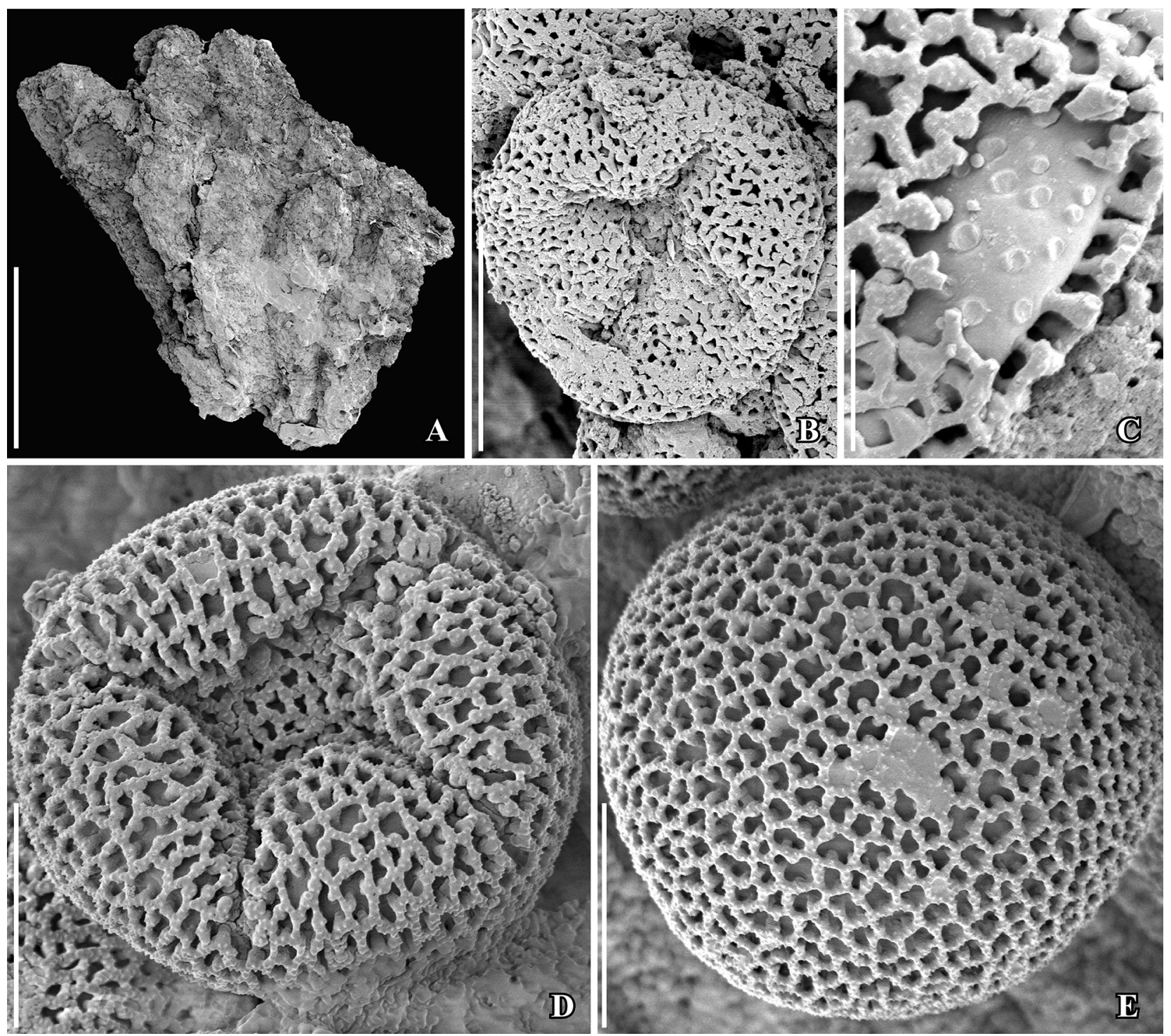

Fig. 3 SEM images of staminate floral structure $(A-C)$ from the Early Cretaceous (late Aptian-early Albian) of Portugal and pollen of extant Hedyosmum angustifolium (Ruiz \& Pav.) Solms $(D, E)$. A-C, Fragment of staminate structure with Asteropollis pollen in situ showing compressed stamens $(A)$, pollen in distal view with tetrachotomocolpate aperture $(B)$ and details of pollen wall $(C)$ with beaded muri and long columellae (S153529; Vale de Água sample 141). D, E Pollen of extant H. angustifolium in distal $(D)$ and proximal $(E)$ views, showing tetrachotomocolpate aperture on the distal surface (no aperture proximally), semitectate-reticulate pollen wall with muri supported by long, scattered columellae and ornamented with minute spines (856 $1978 \mathrm{Kew})$. Scale bars $=500 \mu \mathrm{m}(A), 10 \mu \mathrm{m}(B, D, E), 2.5 \mu \mathrm{m}(C)$.

testal seeds with a single layer of crystal cells, each of which is filled by an endoreticulum of fibers (Friis and Pedersen 2011; Friis et al. 2015). Seeds of extant Hedyosmum differ in having a simple, undifferentiated seed coat, but it has been hypothesized that the endotestal condition is ancestral for Chloranthaceae as a whole (Friis et al. 2015). This is now corroborated by the discovery of Early Cretaceous Hedyosmum-like flowers and fruits with endotestal seeds and a seed coat structure similar to that in Ascarina, Chloranthus, and Sarcandra.

In several phylogenetic analyses of extant and fossil Chloranthaceae (Doyle et al. 2003; Eklund et al. 2004; Doyle and Endress 2018), the Hedyosmum-like fossils were treated collectively as the Asteropollis plant, and Doyle et al. (2003) and
Eklund et al. (2004) scored the Asteropollis plant as having unspecialized testa and tegmen as in extant Hedyosmum. This extrapolation was based on fossil flowers from the Early Cretaceous of Portugal that had been studied only for external morphology. The new SRXTM data presented here provides information about the internal structure of these fossils and reveals a more specialized seed coat structure. This demonstrates that at least some of the plants that produced Asteropollis pollen cannot be assigned to crown group Hedyosmum.

The epigynous flowers of extant Hedyosmum appear very distinct from the apparently perianthless flowers of Ascarina, Chloranthus, and Sarcandra. The discovery of fossil Canrightia flowers that have a semi-inferior ovary and a rudimentary peri- 
anth reduces the gap between extant Hedyosmum and other Chloranthaceae (Friis and Pedersen 2011; Friis et al. 2015). Documentation of an endoreticulate endotesta and a sclerenchymatic tegmen in fossil Hedyflora removes a further point of difference between Hedyosmum and other Chloranthaceae.

\section{Extinct Chloranthoid Diversity and Its Former Distribution}

In addition to Hedyflora crystallifera, four other extinct chloranthoid genera with crystalliferous endotestal seeds, Canrightia, Canrightiopsis, Rightcania E.M.Friis, P.R.Crane \& K.R.Pedersen and Kvacekispermum E.M.Friis, P.R.Crane \& K.R.Pedersen (Friis and Pedersen 2011; Friis et al. 2015; Friis et al. 2018b), have been described from the Early Cretaceous. Rightcania is based on fossil seeds from the Potomac Group of eastern North America, while Canrightia and Canrightiopsis are based on fossil fruits from Portugal. Also from the Early Cretaceous of Portugal are fossil seeds of Kvacekispermum and several related taxa (E. M. Friis, P. R. Crane, and K. R. Pedersen, unpublished manuscript), as well as diverse staminate structures.

In addition to dispersed chloranthoid pollen grains assigned to the genus Asteropollis (see above), pollen grains assigned to Clavatipollenites Couper are of almost worldwide distribution during the Early Cretaceous. Some of these Clavatipollenites pollen grains were undoubtedly produced by early chloranthoids and show clear similarities to pollen of extant Ascarina (Couper 1960; Walker and Walker 1984). However, the fine pollen wall details that define the Ascarina-like Clavatipollenites pollen are difficult to detect in light microscopy (LM), raising questions about the relationships of those Clavatipollenites records based solely on LM studies (Hughes 1994; Friis et al. 2011).

The Late Cretaceous record of Chloranthaceae includes androecia of Chloranthistemon, which are closely similar to those of extant Chloranthus. In some cases, the androecia are attached to a pistil. Such Chloranthus-like fossils are known from Germany (mid-Cretaceous; Hartkopf-Fröder et al. 2011), Sweden (Santonian-Campanian; Crane et al. 1989; Eklund et al. 1997), and North America (Turonian; Herendeen et al. 1993; Campanian; Friis, Crane, and Pedersen, work in progress). Significantly, there are no reliable records of dispersed Asteropollis pollen after the mid-Cretaceous and none of the chloranthoid fruits and seeds recognized in the Early Cretaceous, including Hedyflora and the associated staminate structures, have been reported from Late Cretaceous floras.

The first post-Cretaceous record of Hedyosmum-like pollen (Clavainaperturites microclavatus Hoorn) is from the early Miocene of South America (Martínez et al. 2013), and from the early Miocene onward there is a well-established record of Hedyosmum-like pollen in South and Central America (Martínez et al. 2013), consistent with indications from molecular dating studies that imply secondary diversification in the group during the Neogene (Zhang and Renner 2003), resulting in the $\sim 45$ ex- tant species of Hedyosmum in Central and South America and the West Indies, with only a single outlier species in eastern Asia (Todzia 1993). The present distribution of extant species of Hedyosmum suggests that prior to the Neogene radiation, descendants of the Asteropollis/Hedyflora plants may have survived as relicts across the Laurasian realm through the Late Cretaceous and Cainozoic.

\section{Conclusion}

New observations of the anatomy of Early Cretaceous Hedyosmum-like pistillate structures made possible by SRXTM require their separation from extant Hedyosmum and the establishment of a new genus, Hedyflora. Hedyflora accommodates pistillate Hedyosmum-like fossils that differ from the extant genus in having an endoreticulate and crystalliferous endotesta and a fibrous exotegmen. These results are in accordance with earlier predictions that the endotestal condition is ancestral for the Hedyosmum lineage and for the Chloranthaceae as a whole (Friis et al. 2015). Nevertheless, since Hedyflora is undoubtedly part of the Hedyosmum stem group, these Early Cretaceous fossils provide clear evidence that the divergence between the lineage leading to extant Hedyosmum and other extant Chloranthaceae is very ancient.

Hedyflora, combined with other early records of Chloranthaceae, indicate that during the Early Cretaceous the morphological diversity of chloranthoid flowers was greater than that seen today among the four living genera. In addition, the frequency with which fossil Chloranthaceae are encountered in Early and Late Cretaceous floras, combined with the global distribution of fossil chloranthoid pollen, suggests that this ancient group was much more prominent in Cretaceous vegetation than it is today. Molecular data indicate that there has been diversification at the species level in Chloranthaceae during the Neogene, but in the broader context of the more than $130 \mathrm{Myr}$ history of the family, the four living genera are relictual survivors of a significant ancient diversification that was central in the Cretaceous rise of angiosperms to global vegetational dominance.

\section{Acknowledgments}

We are grateful to Peter K. Endress and an anonymous reviewer for helpful comments. We thank the Paul Scherrer Institut, Villigen, Switzerland, for provision of synchrotron radiation beamtime at the TOMCAT beamline X02DA of the Swiss Light Source and Federica Marone for her help at the beamline. We are also grateful to Anna Lindström for help with the synchrotron radiation X-ray tomographic microscopy analyses. Financial support was provided by the Swiss Light Source (projects 20130185, 20141047, and 20160140) and by the Swedish Research Council (Vetenskapsrådet 2014-5228 to E. M. Friiis).

\section{Literature Cited}

APG (Angiosperm Phylogeny Group) IV 2016 An update of the Angiosperm Phylogeny Group classification for the orders and families of flowering plants: APG IV. Bot J Linn Soc 181:1-20.

Couper RA 1958 British Mesozoic microspores and pollen grains: a systematic and stratigraphic study. Palaeontographica B 103:75-179.
1960 New Zealand Mesozoic and Cainozoic plant microfossils. N Z Geol Surv Paleontol Bull 32:1-87.

Crane PR, EM Friis, KR Pedersen 1989 Reproductive structure and function in Cretaceous Chloranthaceae. Plant Syst Evol 165:211226. 
Dettmann ME, MRA Thomson 1987 Cretaceous palynomorphs from James Ross Island area, Antarctica: a pilot study. Br Antarct Surv Bull 77:13-59.

Dinis JL, J Rey, PP Cunha, P Callapez, R Pena Dos Reis 2008 Stratigraphy and allogenic controls of the western Portugal Cretaceous: an updated synthesis. Cretac Res 29:772-780.

Dinis JL, FP Oliveira, J Rey, IL Duarte 2010 Finding geological heritage: legal issues on private property and fieldwork. The case of outstanding early angiosperms (Barremian to Albian, Portugal). Geoheritage 2:77-90.

Doyle JA, H Eklund, PS Herendeen 2003 Floral evolution in Chloranthaceae: implications of a morphological phylogenetic analysis. Int J Plant Sci 164(suppl):S365-S382.

Doyle JA, PK Endress 2018 Phylogenetic analyses of Cretaceous fossils related to Chloranthaceae and their evolutionary implications. Bot Rev 84:156-202.

Doyle JA, EI Robbins 1977 Angiosperm pollen zonation of the continental Cretaceous of the Atlantic Coastal Plain and its application to deep wells in the Salisbury Embayment. Palynology 1:43-78.

Eklund H, JA Doyle, PS Herendeen 2004 Morphological phylogenetic analysis of living and fossil Chloranthaceae. Int J Plant Sci 165:107-151.

Eklund H, EM Friis, KR Pedersen 1997 Chloranthaceous floral structures from the Late Cretaceous of Sweden. Plant Syst Evol 207:13-42.

Endress PK 1971 Bau der weiblichen Blüten von Hedyosmum mexicanum Cordemoy (Chloranthaceae). Bot Jahrb Syst 91:39-60.

1987 The Chloranthaceae: reproductive structures and phylogenetic position. Bot Jahrb Syst 109:153-226.

Friis EM, PR Crane, KR Pedersen 1997 Fossil history of magnoliid angiosperms. Pages 121-156 in K Iwatsuki, PH Raven, eds. Evolution and diversification of land plants. Springer, Tokyo.

Friis EM, PR Crane, KR Pedersen 2011 Early flowers and angiosperm evolution. Cambridge University Press, Cambridge.

2018 a Extinct taxa of exotestal seeds close to Austrobaileyales and Nymphaeales from the Early Cretaceous of Portugal. Fossil Imprint 74:135-158.

2018b Rightcania and Kvacekispermum: Early Cretaceous seeds from eastern North America and Portugal provide further evidence of the early chloranthoid diversification. Fossil Imprint 74:65-76.

Friis EM, GW Grimm, MM Mendes, KR Pedersen 2015 Canrightiopsis, a new Early Cretaceous fossil with Clavatipollenites-type pollen bridge the gap between extinct Canrightia and extant Chloranthaceae. Grana 54:184-212.

Friis EM, F Marone, KR Pedersen, PR Crane, M Stampanoni 2014 Three-dimensional visualization of fossil flowers, fruits, seeds and other plant remains using synchrotron radiation X-ray tomographic microscopy (SRXTM): new insights into Cretaceous plant diversity. J Paleontol 88:684-701.

Friis EM, KR Pedersen 2011 Canrightia resinifera gen. et sp. nov., a new extinct angiosperm with Retimonocolpites-type pollen from the
Early Cretaceous of Portugal: missing link in the eumagnoliid tree? Grana 50:3-29.

Friis EM, KR Pedersen, PR Crane 2005 When earth started blooming: insights from the fossil record. Curr Opin Plant Biol 8:1-8.

2009 Early Cretaceous mesofossils from Portugal and eastern North America related to the Bennettitales-ErdtmanithecalesGnetales group. Am J Bot 96:252-283.

Hartkopf-Fröder C, J Rust, T Wappler, EM Friis, A Viehofen 2011 Mid-Cretaceous charred fossil flowers reveal direct observation of arthropod feeding strategies. Biol Lett 8: 295-298.

Hedlund RW, G Norris 1968 Spores and pollen grains from Fredericksburgian (Albian) strata, Marshall County, Oklahoma. Pollen et Spores 10:129-159.

Herendeen PS, WL Crepet, KC Nixon 1993 Chloranthus-like stamens from the Upper Cretaceous of New Jersey. Am J Bot 80:865-871.

Hughes NF 1994 The enigma of angiosperm origins. Cambridge University Press, Cambridge.

Koppelhus EB, GK Pedersen 1993 A palynological and sedimentological study of Cretaceous floodplain deposits of the Atane Formation at Skansen and Igdlunguaq, Disko, West Greenland. Cretac Res 14:707-734.

Legrand J, T Yamada, H Nishida 2014 Palynofloras from the upper Barremian-Aptian Nishihiro Formation (Outer Zone of southwest Japan) and the appearance of angiosperms in Japan. J Plant Res 127:221-232.

Martínez C, S Madriñán, M Zavada, CA Jaramillo 2013 Tracing the fossil pollen record of Hedyosmum (Chloranthaceae), an old lineage with recent Neotropical diversification. Grana 52:161-180.

Nichols DJ, M Matsukawa, M Ito 2006 Palynology and age of some Cretaceous nonmarine deposits in Mongolia and China. Cretac Res 27:241-251.

Song ZC, WM Wang, F Huang 2004 Fossil pollen records of extant angiosperms in China. Bot Rev 70:425-458.

Stampanoni, M, A Groso, A Isenegger, G Mikuljan, Q Chen, A Bertrand, S Henein, et al 2006 Trends in synchrotron-based tomographic imaging: the SLS experience. In U Bonse, ed. Proceedings of SPIE. Vol 6318. Developments in X-ray tomography V, 63180M (7 September 2006); doi: 10.1117/12.679497.

Swamy BGL 1953 The morphology and relationships of the Chloranthaceae. J Arnold Arbor Harv Univ 34:375-411.

Todzia CA 1993 Chloranthaceae. Pages 281-289 in K Kubitzki, JG Rohwer, V Bittrich, eds. The families and genera of vascular plants. Vol II. Flowering plants, dicotyledons: magnoliid, hamamelid and caryophyllid families. Springer, Berlin.

Walker JW, AG Walker 1984 Ultrastructure of Lower Cretaceous angiosperm pollen and the origin and early evolution of flowering plants. Ann Mo Bot Gard 71:464-521.

Zhang L-B, SS Renner 2003 The deepest splits in Chloranthaceae as resolved by chloroplast sequences. Int J Plant Sci 164(suppl):S383S392. 